Cite this: New J. Chem., 2014, 38, 1559

\begin{abstract}
Received (in Montpellier, France) 22nd November 2013,

Accepted 30th January 2014
\end{abstract}

DOI: $10.1039 / c 3 n j 01457 f$

www.rsc.org/njc

\title{
New small molecules with thiazolothiazole and benzothiadiazole acceptors for solution- processed organic solar cells
}

\author{
Yanhua Chen, $\dagger^{\mathrm{ab}}$ Zhengkun Du, $\dagger^{\mathrm{b}}$ Weichao Chen, ${ }^{\mathrm{b}}$ Shuguang Wen, ${ }^{\mathrm{b}}$ Liang Sun, ${ }^{\mathrm{b}}$ \\ Qian Liu, ${ }^{a b}$ Mingliang Sun*a and Renqiang Yang*b
}

A new thiazolothiazole based small molecule (DTTz-DTBTT) has been designed and synthesized. The small molecule exhibited good thermal stability and excellent solubility. The optical gap of DTTz-DTBTT was estimated to be $1.65 \mathrm{eV}$. The solution-processed photovoltaic device based on DTTz-DTBTT and $\mathrm{PC}_{61} \mathrm{BM}$ exhibited a power conversion efficiency of $1.64 \%$.

\section{Introduction}

Organic solar cells (OSCs) have been extensively investigated due to their unique features, such as low energy consumption, mechanical flexibility, large area coverage and low-cost manufacturing. ${ }^{1-3}$ In the past decade, intensive interdisciplinary efforts have been dedicated to improving the power conversion efficiencies (PCEs) of solar cells. ${ }^{4,5}$ Solution-processed solar cells based on $\pi$-conjugated polymers and fullerene derivatives have reached over $9 \%$ PCEs, ${ }^{6}$ and the perovskite-sensitized solar cells have shown exciting $15 \%$ PCEs. $^{7}$ Bulk heterojunction $(\mathrm{BHJ})$ structure, which increases the donor-acceptor (D-A) interface areas for photo-induced exciton dissociation in the active layer by forming an interpenetrating network of electron donor and acceptor components, has become one of the most successful device structures developed to date. ${ }^{8,9}$ More recently, the PCEs have been rapidly increasing in solution-processed small molecule OSCs. ${ }^{10-12}$ One main advantage of small molecule OSCs over polymeric counterparts is their facile characterization and purification. ${ }^{13}$ The purification of semiconducting materials has recently been proven to be crucial to achieve high PCEs in "small molecule" OSCs. ${ }^{14}$ However, solution-processed small molecule OSCs containing low-molecular-weight compounds as donors showed relatively low efficiencies due to the unmatched sizes of donors and acceptors. ${ }^{15}$ At this point, the small molecular design strategies for new donor materials with appropriate physical properties such as low band-gap and suitable energy

\footnotetext{
${ }^{a}$ Institute of Material Science and Engineering, Ocean University of China, Qingdao 266100, People's Republic of China. E-mail: mlsun@ouc.edu.cn; Fax: +86-532-66781927; Tel: +86-532-66781690

${ }^{b}$ Qingdao Institute of Bioenergy and Bioprocess Technology, Chinese Academy of Sciences, Qingdao 266101, People's Republic of China.

E-mail: yangrq@qibebt.ac.cn; Fax: +86-532-80662778; Tel: +86-532-80662700

$\dagger$ These authors contribute equally to this work.
}

levels have been employed to improve the performance of OSCs. Among them, a large number of small molecules with donor-acceptor (D-A) architectures have been successfully applied as solar cell donors and exhibited excellent device performances. ${ }^{16,17}$ By varying D-A segment chemical structure, these D-A type organic small molecules exhibited a wide absorption spectrum and suitable energy levels which could contribute to the open circuit voltage $\left(V_{\text {OC }}\right)$ and efficient exciton dissociation in solar cell devices. ${ }^{16,17}$ The PCEs of solutionprocessed OSCs based on D-A low band-gap small molecules as donors have exceeded $8 \%$, as reported by groups of Y. S. Chen and G. C. Bazan, respectively. ${ }^{18,19}$ In order to obtain a broad absorption spectrum and lower energy levels of small molecules, the introduction of two different acceptors into the conjugated small molecule backbone may be a good choice. However, there were very few small molecule OSC donor materials, based on two different acceptors units, exhibiting remarkable success. ${ }^{20}$ Recently, the small molecule donor materials with two acceptor units have achieved PCEs of 3.07-5.5\%, which are promising donor materials for solution-processed OSCs. ${ }^{16-20}$ A further study on this type of solution-processed small molecule OSCs is underway.

Thiazolothiazole $(\mathrm{Tz})$ has a rigid and coplanar fused ring, thereby ensuring a highly extended $\pi$-electron system and strong $\pi-\pi$ stacking. As a result, conjugated small molecules and polymers based on $\mathrm{Tz}$ units exhibited high charge carrier mobilities. ${ }^{21,22}$ Recently, several thiazolothiazole-based copolymers and small molecules have been successfully applied in organic solar cells. ${ }^{23}$ Among the variety of developed acceptor units, benzothiadiazole (BT) has attracted much attention because of its special properties of controlling the energy levels in D-A conjugated molecules. ${ }^{24-26}$ High performance OSCs were achieved by blending BT-based copolymers and fullerene derivatives, such as benzo[1,2- $b: 4,5-$ $b^{\prime}$ ]dithiophene-BT, ${ }^{27}$ diketopyrrolopyrrole-BT, ${ }^{28}$ and carbazole$\mathrm{BT}^{29}$ Thus, Tz and BT units could be employed in the design of 


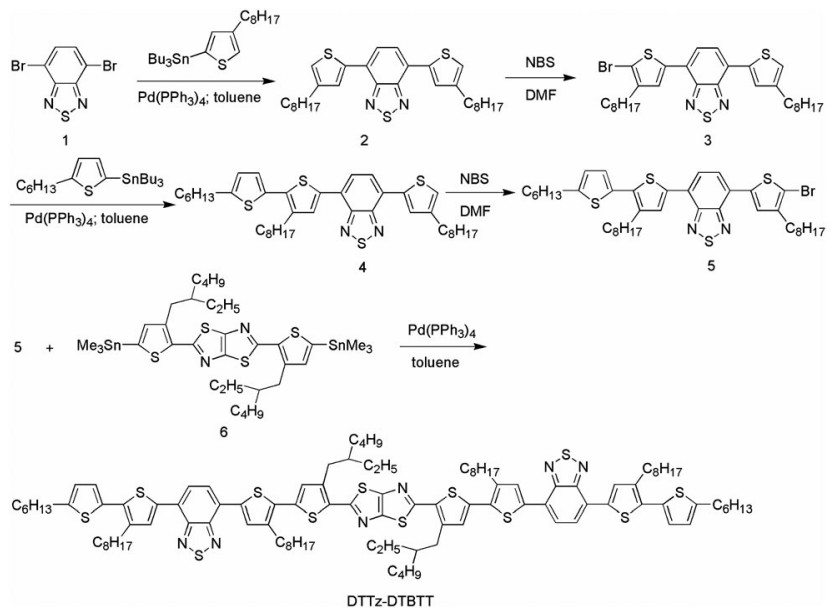

Scheme 1 Synthetic route for preparation of DTTz-DTBTT.

semiconductive small molecules for solution-processed OSC applications.

In this work, we reported a new conjugated small molecule, DTTz-DTBTT, using the Tz unit as the central core, thiophene as the $\pi$-bridge, and BT as the acceptor unit (Scheme 1). The targeted molecule has good solubility in common organic solvents, such as dichloromethane $\left(\mathrm{CH}_{2} \mathrm{Cl}_{2}\right)$, chloroform $\left(\mathrm{CH}_{3} \mathrm{Cl}\right)$ and tetrahydrofuran (THF). The optical gap of DTTz-DTBTT estimated from the absorption onset of thin film was $1.65 \mathrm{eV}$ with a highest occupied molecular orbital (HOMO) level of around $-5.05 \mathrm{eV}$. The solutionprocessed OSCs based on DTTz-DTBTT were investigated in typical $\mathrm{BHJ}$ devices using $\mathrm{PC}_{61} \mathrm{BM}$ as an acceptor.

\section{Experimental}

\section{General}

All starting reagents were purchased commercially as analytical reagents and used directly without any purification. $N, N$-Dimethylformamide (DMF) was purified by vacuum distillation. Toluene was dried over sodium with benzophenone as an indicator. The sample was dried at $40{ }^{\circ} \mathrm{C}$ under vacuum. Compounds 4,7-dibromo-benzo[1,2,5]thiadiazole $(\mathbf{1})^{30}$ and 2,5-bis(trimethyltin4-(2-ethylhexyl)thiophen-2-yl)-thiazolo[5,4- $d]$ thiazole $(\mathbf{6})^{23}$ were prepared according to the literature.

NMR spectroscopy was carried out on a Bruker Advance III 600 spectrometer using tetramethylsilane as an internal standard. High resolution mass spectra were recorded on a Bruker Maxis UHR TOF spectrometer in APCI mode. UV-vis absorption spectroscopy was carried out on a Hitachi U-4100 spectrophotometer. Cyclic voltammograms were measured on a CHI660D electrochemical workstation. Surface roughness and morphology of thin films were characterized by atomic force microscopy (AFM) on an Agilent 5400 .

\section{Synthesis}

Synthesis of DTBT (2). 4,7-Dibromo-benzo[1,2,5]thiadiazole (1) $(2.94 \mathrm{~g}, 10 \mathrm{mmol})$, tributyl-(4-octyl-thiophen-2-yl)-stannane $(10.7 \mathrm{~g}, 22 \mathrm{mmol})$ and $\mathrm{Pd}\left(\mathrm{PPh}_{3}\right)_{4}(0.35 \mathrm{~g}, 0.3 \mathrm{mmol})$ were dissolved in $80 \mathrm{ml}$ of anhydrous degassed toluene. The reaction mixture was heated up to $110{ }^{\circ} \mathrm{C}$ and stirred overnight under argon. Then the cooled mixture was poured into ice water and extracted with $\mathrm{CH}_{2} \mathrm{Cl}_{2}$. The combined organic layer was dried over $\mathrm{Na}_{2} \mathrm{SO}_{4}$ and concentrated under reduced pressure. The crude residue was purified by column chromatography over silica gel with petroleum ether: $\mathrm{CH}_{2} \mathrm{Cl}_{2}$ as an eluent and compound (2) was obtained as a light red solid (4.46 g, 85\%).

${ }^{1} \mathrm{H}$ NMR $\left(600 \mathrm{MHz}, \mathrm{CDCl}_{3}, \delta\right): 7.96(\mathrm{~s}, 2 \mathrm{H}), 7.79(\mathrm{~s}, 2 \mathrm{H}), 7.02$ $(\mathrm{s}, 2 \mathrm{H}), 2.68(\mathrm{t}, 4 \mathrm{H}), 1.68(\mathrm{~m}, 4 \mathrm{H}), 1.53-1.28(\mathrm{~m}, 20 \mathrm{H}), 0.89-0.86$ $(\mathrm{m}, 6 \mathrm{H})$.

${ }^{13} \mathrm{C}$ NMR $\left(150 \mathrm{MHz}, \mathrm{CDCl}_{3}, \delta\right): 152.61,144.35,139.00$, $128.99,125.98,125.49,121.50,31.91,30.66,30.52,29.47$, 29.40, 29.30, 22.69, 14.13 .

Synthesis of DTBT-Br (3). Compound (2) $(4.2 \mathrm{~g}, 8 \mathrm{mmol})$ was dissolved in $60 \mathrm{ml}$ of DMF at room temperature, and $N$-bromosuccinimide (NBS) $(1.42 \mathrm{~g}, 8 \mathrm{mmol})$ was added slowly. After stirring under the light protection overnight, the reaction mixture was poured into ice water and extracted with chloroform. The organic layer was washed with water and brine and dried with anhydrous $\mathrm{Na}_{2} \mathrm{SO}_{4}$, then filtered. The solvent was evaporated under reduced pressure. The dark solid was purified by column chromatography with $\mathrm{CH}_{2} \mathrm{Cl}_{2}$ :petroleum ether as an eluent and a red solid (3) (1.92 g, 40\%) was obtained.

${ }^{1} \mathrm{H}$ NMR $\left(600 \mathrm{MHz}, \mathrm{CDCl}_{3}, \delta\right): 7.96(\mathrm{~s}, 1 \mathrm{H}), 7.77(\mathrm{~d}, 1 \mathrm{H}), 7.73$ (s, 1H), $7.71(\mathrm{~d}, 1 \mathrm{H}), 7.03(\mathrm{~s}, 1 \mathrm{H}), 2.68(\mathrm{t}, 2 \mathrm{H}), 2.62(\mathrm{t}, 2 \mathrm{H}), 1.68$ $(\mathrm{m}, 4 \mathrm{H}), 1.40-1.25(\mathrm{~m}, 20 \mathrm{H}), 0.89-0.86(\mathrm{~m}, 6 \mathrm{H})$.

${ }^{13} \mathrm{C}$ NMR $\left(150 \mathrm{MHz}, \mathrm{CDCl}_{3}, \delta\right): 152.47,152.30,144.41$, 142.98, 138.84, 138.64, 129.17, 127.86, 126.39, 125.32, 124.92, 124.91, 121.71, 111.34, 31.90, 30.65, 30.51, 29.79, 29.69, 29.47, 29.42, 29.40, 29.31, 29.30, 29.28, 22.69, 14.13.

Synthesis of DTBT-T (4). Compound (3) (1.81 g, $3 \mathrm{mmol})$, tributyl-(5-hexyl-thiophen-2-yl)-stannane $(1.5 \mathrm{~g}, 3.3 \mathrm{mmol})$ and $\mathrm{Pd}\left(\mathrm{PPh}_{3}\right)_{4}(35 \mathrm{mg}, 0.03 \mathrm{mmol})$ were dissolved in $30 \mathrm{ml}$ of anhydrous degassed toluene. The reaction mixture was heated up to $110{ }^{\circ} \mathrm{C}$ and stirred overnight under argon. Then the cooled mixture was poured into water and extracted with $\mathrm{CH}_{2} \mathrm{Cl}_{2}$. The combined organic layer was dried over $\mathrm{Na}_{2} \mathrm{SO}_{4}$ and concentrated under reduced pressure. The crude residue was purified by column chromatography over silica gel with petroleum ether: $\mathrm{CH}_{2} \mathrm{Cl}_{2}$ as an eluent and compound (4) was obtained as a dark red solid (1.55 g, 75\%).

${ }^{1} \mathrm{H}$ NMR $\left(600 \mathrm{MHz}, \mathrm{CDCl}_{3}, \delta\right): 7.96(\mathrm{~s}, 1 \mathrm{H}), 7.95(\mathrm{~s}, 1 \mathrm{H}), 7.76$ $(\mathrm{m}, 2 \mathrm{H}), 7.03(\mathrm{~s}, 1 \mathrm{H}), 7.02(\mathrm{~d}, 1 \mathrm{H}), 6.75(\mathrm{~d}, 1 \mathrm{H}), 2.81(\mathrm{~m}, 4 \mathrm{H})$, $2.68(\mathrm{t}, 2 \mathrm{H}), 1.70(\mathrm{~m}, 6 \mathrm{H}), 1.40-1.25(\mathrm{~m}, 26 \mathrm{H}), 0.89-0.86(\mathrm{~m}, 9 \mathrm{H})$.

${ }^{13} \mathrm{C}$ NMR $\left(150 \mathrm{MHz}, \mathrm{CDCl}_{3}, \delta\right): 152.44,152.36,146.61$, 143.01, 139.91, 138.71, 136.16, 133.36, 133.24, 130.83, 127.83, $125.88,125.76,124.99,124.94,124.81,124.51,111.34,31.91$, $31.90,31.59,30.64,30.19,29.79,29.69,29.63,29.49,29.45$, 29.42, 29.31, 29.28, 28.84, 22.70, 22.69, 22.60, 14.14, 14.13, 14.10 .

Synthesis of DTBTT-Br (5). Compound (4) (1.38 g, $2 \mathrm{mmol})$ was dissolved in $40 \mathrm{ml}$ of DMF at room temperature, NBS ( $374 \mathrm{mg}, 2.1 \mathrm{mmol}$ ) was added slowly. After stirring under the light protection overnight, the reaction mixture was poured into ice water and extracted with $\mathrm{CH}_{2} \mathrm{Cl}_{2}$. The organic layer was washed with water and brine and dried with anhydrous $\mathrm{Na}_{2} \mathrm{SO}_{4}$, then filtered. The solvent was evaporated under reduced pressure. 
The dark solid was purified by column chromatography with $\mathrm{CH}_{2} \mathrm{Cl}_{2}$ :petroleum ether as an eluent and a dark red solid (5) (1.38 g, 90\%) was obtained.

${ }^{1} \mathrm{H}$ NMR (600 MHz, $\left.\mathrm{CDCl}_{3}, \delta\right): 7.96(\mathrm{~s}, 1 \mathrm{H}), 7.77(\mathrm{~d}, 1 \mathrm{H}), 7.75$ $(\mathrm{s}, 1 \mathrm{H}), 7.73(\mathrm{~d}, 1 \mathrm{H}), 7.03(\mathrm{~d}, 1 \mathrm{H}), 6.75(\mathrm{~d}, 1 \mathrm{H}), 2.83(\mathrm{~m}, 4 \mathrm{H}), 2.63$ (t, 2H), $1.72(\mathrm{~m}, 6 \mathrm{H}), 1.44-1.28(\mathrm{~m}, 26 \mathrm{H}), 0.91-0.87$ (m, 9H).

${ }^{13} \mathrm{C}$ NMR (150 MHz, $\left.\mathrm{CDCl}_{3}, \delta\right): 152.44,152.36,146.61$, 143.01, 139.91, 138.71, 136.16, 133.36, 133.24, 130.83, 127.83, $125.88,125.76,124.99,124.94,124.81,124.51,111.34,31.91$, $31.90,31.59,30.64,30.19,29.79,29.69,29.63,29.49,29.45$, 29.42, 29.31, 29.28, 28.84, 22.70, 22.69, 22.60, 14.14, 14.13, 14.10.

Synthesis of DTTz-DTBTT. Compound (5) $(385 \mathrm{mg}$, $0.5 \mathrm{mmol}$ ), 2,5-bis(trimethyltin-4-(2-ethylhexyl)thiophen-2-yl)thiazolo[5,4- $d$ ] thiazole $(6)(171 \mathrm{mg}, 0.2 \mathrm{mmol})$ and $\mathrm{Pd}\left(\mathrm{PPh}_{3}\right)_{4}$ (23 $\mathrm{mg}, 0.02 \mathrm{mmol}$ ) were dissolved in $20 \mathrm{ml}$ of anhydrous degassed toluene. The reaction mixture was heated up to $110{ }^{\circ} \mathrm{C}$ and stirred at this temperature for $48 \mathrm{~h}$ under argon. Then the cooled mixture was poured into water and extracted with diethyl ether. The combined organic layer was dried over $\mathrm{Na}_{2} \mathrm{SO}_{4}$ and concentrated under reduced pressure. The crude residue was purified by column chromatography over silica gel with petroleum ether: $\mathrm{CH}_{2} \mathrm{Cl}_{2}$ (2:1) as the eluent and compound DTTz-DTBTT was obtained as a dark purple solid $(110 \mathrm{mg}, 31 \%)$.

${ }^{1} \mathrm{H}$ NMR (600 MHz, $\mathrm{CDCl}_{3}, \delta$ ): $7.96(\mathrm{~s}, 4 \mathrm{H}), 7.77(\mathrm{~m}, 4 \mathrm{H}), 7.05$ $(\mathrm{s}, 2 \mathrm{H}), 7.02(\mathrm{~d}, 2 \mathrm{H}), 6.75(\mathrm{~d}, 2 \mathrm{H}), 2.91(\mathrm{~m}, 8 \mathrm{H}), 2.83(\mathrm{t}, 4 \mathrm{H}), 2.80$ $(\mathrm{t}, 4 \mathrm{H}), 1.84(\mathrm{~m}, 2 \mathrm{H}), 1.78(\mathrm{~m}, 4 \mathrm{H}), 1.72(\mathrm{~m}, 8 \mathrm{H}), 1.51-1.29$ $(\mathrm{m}, 68 \mathrm{H}), 0.97-0.88(\mathrm{~m}, 30 \mathrm{H})$.

${ }^{13} \mathrm{C}$ NMR (150 MHz, $\left.\mathrm{CDCl}_{3}, \delta\right): 160.83,152.47,150.04$, 146.48, 142.45, 141.31, 139.80, 137.48, 137.45, 136.21, 133.37, $133.15,131.87,131.82$, 130.66, 130.62, 129.60, 125.67, 125.63, $125.47,125.27,124.88,124.83,124.47,39.61,39.60,34.77$, $32.63,31.96,31.94,31.61,31.59,30.61,30.37,30.19,29.95$, $29.78,29.74,29.72,29.69,29.61,29.58,29.53,29.48,29.38$, 29.35, 28.87, 28.69, 14.22, 14.17, 14.15, 14.13, 14.11, 10.73.

MS (UHR-TOF) $m / z\left[\mathrm{M}^{+}\right]=1909.8058$ (calcd for $\mathrm{C}_{108} \mathrm{H}_{142} \mathrm{~N}_{6} \mathrm{~S}_{12}$, 1909.8074).

\section{Devices fabrication}

Photovoltaic devices were fabricated by a simple spin-coating process, with a general device structure of glass/ITO/PEDOT:PSS/DTTz-DTBTT:PC ${ }_{61} \mathrm{BM} / \mathrm{Ca} / \mathrm{Al}$. The ITO-coated glasses were ultrasonically cleaned with acetone, toluene, methanol, and isopropyl alcohol, subsequently. Oxygen plasma treatment was done for $10 \mathrm{~min}$ as the final step of substrate cleaning to improve the contact angle just before film coating. Onto the ITO glass a layer of polyethylenedioxythiophene-polystyrene sulfonic acid (PEDOT:PSS) film was spin-coated from its aqueous dispersion with a thickness of $40 \mathrm{~nm}$. PEDOT:PSS film was dried at $160{ }^{\circ} \mathrm{C}$ for $30 \mathrm{~min}$ in the vacuum oven. The solution of the DTTz-DTBTT and fullerenes in $\mathrm{CHCl}_{3}$ was prepared in a nitrogen-filled dry box (Vacuum Atmosphere Co.) and spincoated on the top of the ITO/PEDOT. The typical thickness of the active layer was $100 \mathrm{~nm}$. Typical concentration of the small molecule/ $/ \mathrm{PC}_{61} \mathrm{BM}$ blending solution used in this study for the spin-coating active layer was $10 \mathrm{mg} \mathrm{ml} \mathrm{m}^{-1}$. Subsequently Ca $(10 \mathrm{~nm})$ and $\mathrm{Al}(100 \mathrm{~nm})$ were thermally evaporated under a vacuum of $2 \times 10^{-4} \mathrm{~Pa}$ on the top of the active layer as a cathode. Current-voltage $(I-V)$ characteristics were measured under illumination of the AM 1.5G solar simulator with $100 \mathrm{~mW} \mathrm{~cm}^{-2}$ power. The external quantum efficiency (EQE) was measured using a source meter, silicon photodiode and a computer-controlled light sourcemonochromator-Lock-in system. ${ }^{12 b}$

\section{Result and discussion}

\section{Synthesis and thermal stability}

The synthetic route for preparation of small molecules, DTTzDTBTT, is outlined in Scheme 1. Compound (5) was synthesized through a four-step reaction of compound 4,7-dibromobenzo[1,2,5]thiadiazole (1) using Stille coupling and bromination reactions. The targeted molecule was synthesized by Stille coupling between compound (5) and 2,5-bis(trimethyltin-4-(2ethylhexyl)thiophen-2-yl)-thiazolo $[5,4-d]$ thiazole (6). ${ }^{23}$ All the synthesis process and the purification procedure were all well repeated with moderate and high yields. The purity of the targeted compound for the device fabrication was guaranteed by repeated column purification. The small molecule was soluble in common organic solvents, which was a prerequisite for solutionprocessed small molecule OSCs. The thermal properties of DTTzDTBTT were investigated by thermogravimetric analysis (TGA) using a differential scanning calorimeter (DSC). This molecule exhibited good thermal stability with a decomposition temperature ( $5 \%$ weight loss) of $419^{\circ} \mathrm{C}$ and a DSC melting point at $170{ }^{\circ} \mathrm{C}$ in nitrogen (Fig. 1). The high thermal stability of the small molecule decreases the possibility of molecule degradation and morphology deformation in solar cells. ${ }^{31,32}$

\section{Optical properties}

Fig. 2 showed the normalized UV-vis absorption of DTTz-DTBTT in dilute $\mathrm{CHCl}_{3}$ solution and in thin solid film. The UV-vis optical spectrum of DTTz-DTBTT in chloroform presented an absorption peak at $535 \mathrm{~nm}$. The thin film of DTTz-DTBTT showed intense absorption throughout the visible region $(300-700 \mathrm{~nm})$. The film exhibited an obvious red-shifted $\lambda_{\max }=587 \mathrm{~nm}$ absorption.

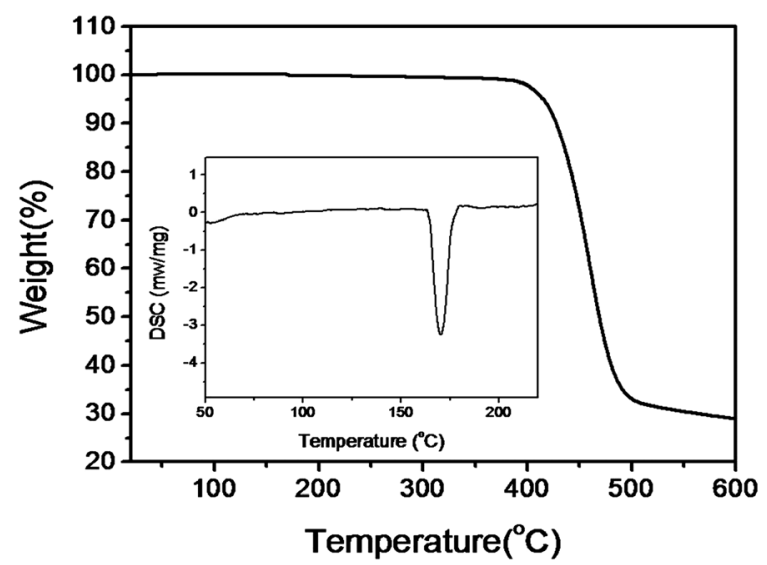

Fig. 1 TGA and DSC plots of DTTz-DTBTT at the heating rate of $10{ }^{\circ} \mathrm{C} \mathrm{min}^{-1}$ under a nitrogen atmosphere. 


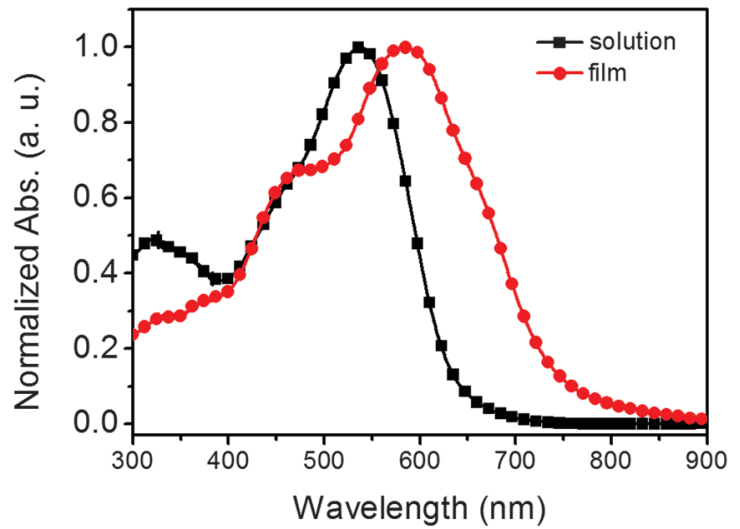

Fig. 2 UV-vis absorption spectra of DTTz-DTBTT in chloroform solution and in thin solid film.

Compared to that in solution, the absorption spectrum of the film as well as its red-shift $(52 \mathrm{~nm})$ suggested that strong intermolecular interaction and aggregation existed in the film. The optical gap of DTTz-DTBTT was estimated to be $1.65 \mathrm{eV}$ from the absorption onset $(752 \mathrm{~nm})$ in the thin film.

\section{Electrochemical properties}

The electrochemical properties of DTTz-DTBTT were investigated by cyclic voltammetry (CV) as film on a glassy carbon working electrode in $0.1 \mathrm{M}\left[{ }^{n} \mathrm{Bu}_{4} \mathrm{~N}\right]^{+}\left[\mathrm{PF}_{6}\right]^{-} \mathrm{CH}_{3} \mathrm{CN}$ solution $\left({ }^{n} \mathrm{Bu}=n\right.$-butyl $)$ at a potential scan rate of $100 \mathrm{mV} \mathrm{s}^{-1}$. As shown in Fig. 3, DTTz-DTBTT exhibited a couple of reversible reduction wave and quasi-reversible oxidation wave. The redox potential of the $\mathrm{Fc} / \mathrm{Fc}^{+}$internal reference was $0.38 \mathrm{~V}$ vs. SCE.

The HOMO and lowest unoccupied molecular orbital (LUMO) energy levels of the molecule were determined by the empirical formula of $E_{\mathrm{HOMO}}=-\mathrm{e}\left(E_{\mathrm{Ox}}+4.8-E_{1 / 2,\left(\mathrm{Fc} / \mathrm{Fc}^{+}\right)}\right), E_{\mathrm{LUMO}}=$ $-\mathrm{e}\left(E_{\text {Red }}+4.8-E_{1 / 2,\left(\mathrm{Fc}_{\mathrm{Fc}}+{ }^{+}\right)}\right)$. The onset oxidation and reduction potentials of DTTz-DTBTT were $0.63 \mathrm{~V}$ and $-1.35 \mathrm{~V}$, thus the corresponding HOMO and LUMO energy levels were $-5.05 \mathrm{eV}$ and $-3.07 \mathrm{eV}$, respectively.

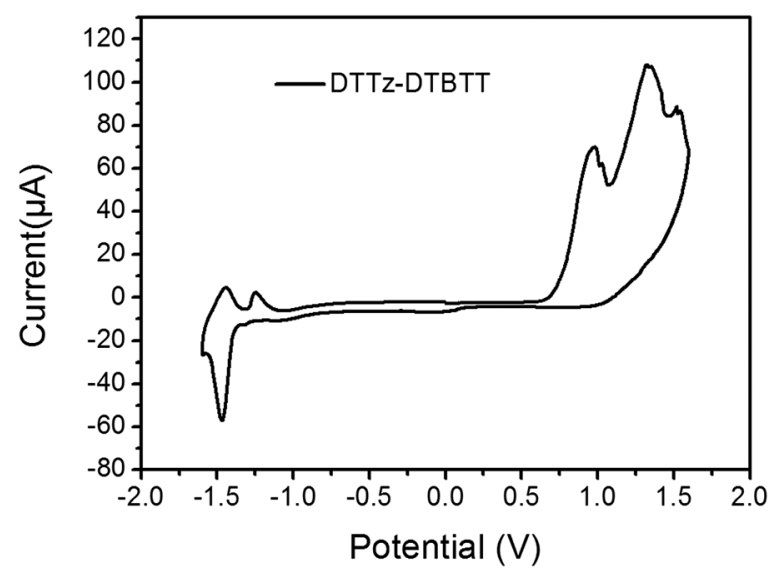

Fig. 3 Cyclic voltammogram of DTTz-DTBTT molecules.

\section{Photovoltaic properties}

$\mathrm{BHJ}$ OSCs were fabricated with a device structure of glass/ITO/ PEDOT:PSS/DTTz-DTBTT:PC ${ }_{61} \mathrm{BM} / \mathrm{Ca} / \mathrm{Al}$, and tested under a simulated AM 1.5G illumination at $100 \mathrm{~mW} \mathrm{~cm}^{-2}$. The blends of the DTTz-DTBTT and $\mathrm{PC}_{61} \mathrm{BM}$ at different weight ratios of $1: 2,1: 1$, and $2: 1$ were used to optimize the device performances and their current density versus voltage $(J-V)$ curves were shown in Fig. 4, and for all the optimized conditions, we had averaged the performance over 5 devices and the data were given in Table 1 . Finally, the PCE of $1.64 \%$ for DTTz-DTBTT was obtained with an open-circuit voltage $\left(V_{\mathrm{OC}}\right)$ of $0.66 \mathrm{~V}$, a short circuit current density $\left(J_{\mathrm{SC}}\right)$ of $5.11 \mathrm{~mA} \mathrm{~cm}{ }^{-2}$, and a fill factor (FF) of $48 \%$, when the device was made at a donor-acceptor weight ratio of $1: 1$ in chloroform with a concentration of $10 \mathrm{mg} \mathrm{ml}{ }^{-1}$, spun cast at $1500 \mathrm{rpm}$. The devices fabricated with DTTz-DTBTT exhibited moderate performance that could be caused by a low $V_{\text {OC }}$ of $0.66 \mathrm{~V}$. The $V_{\text {OC }}$ was governed by the gap between the HOMO level of DTTz-DTBTT and the LUMO of PCBM $(-3.9 \mathrm{eV}$ to $-4.2 \mathrm{eV}) .{ }^{12 c, 23}$ Thus, the high HOMO level $(-5.05 \mathrm{eV})$ of DTTz-DTBTT caused lower $V_{\mathrm{OC}}$ in this case.

The external quantum efficiency (EQE) curve of the optimized $\mathrm{BHJ}$ device based on DTTz-DTBTT/PC ${ }_{61} \mathrm{BM}(\mathrm{w}: \mathrm{w}, 1: 1)$ is shown in Fig. 5. The EQE curve exhibits a monochromatic EQE maximum of $28 \%$ at $442 \mathrm{~nm}$ and a broad response covering at $350-750 \mathrm{~nm}$, consistent with the absorption spectrum. This EQE value indicates that the photoresponse is moderate for this small molecule based $\mathrm{BHJ}$ device. The $J_{\mathrm{SC}}$ calculated from the integral of EQE curve based on DTTz-DTBTT with an AM 1.5G reference spectrum is $5.02 \mathrm{~mA} \mathrm{~cm}^{-2}$, which is consistent with the $J_{\mathrm{SC}}$ value obtained from the $J-V$ measurement $\left(5.11 \mathrm{~mA} \mathrm{~cm}^{-2}\right)$.

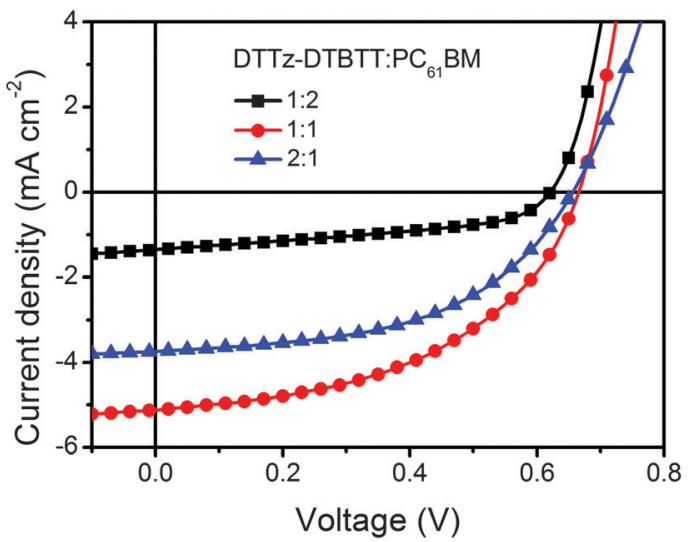

Fig. $4 \mathrm{~J}-V$ curves of the OSCs based on DTTz-DTBTT:PC ${ }_{61} B M$ under the

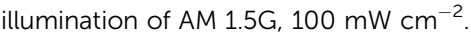

Table 1 Solar cells performance of DTTz-DTBTT: $C_{61}$ BM with different blend ratios

\begin{tabular}{llllll}
\hline Small molecule & Ratio & $\begin{array}{l}V_{\mathrm{OC}} \\
(\mathrm{V})\end{array}$ & $\begin{array}{l}J_{\mathrm{SC}} \\
\left(\mathrm{mA} \mathrm{cm}{ }^{-2}\right)\end{array}$ & $\begin{array}{l}\mathrm{FF} \\
(\%)\end{array}$ & $\begin{array}{l}\mathrm{PCE}_{\max } / \\
\mathrm{PCE}_{\text {ave }}(\%)\end{array}$ \\
\hline DTTz-DTBTT: $\mathrm{PC}_{61} \mathrm{BM}$ & $1: 2$ & 0.62 & 1.35 & 46.2 & $0.39 / 0.35 \pm 0.03$ \\
DTTz-DTBTT: PC $_{61} \mathrm{BM}$ & $1: 1$ & 0.66 & 5.11 & 48.3 & $1.64 / 1.58 \pm 0.03$ \\
DTTz-DTBTT $:$ PC $_{61} \mathrm{BM}$ & $2: 1$ & 0.66 & 3.73 & 51.1 & $1.25 / 1.23 \pm 0.02$
\end{tabular}




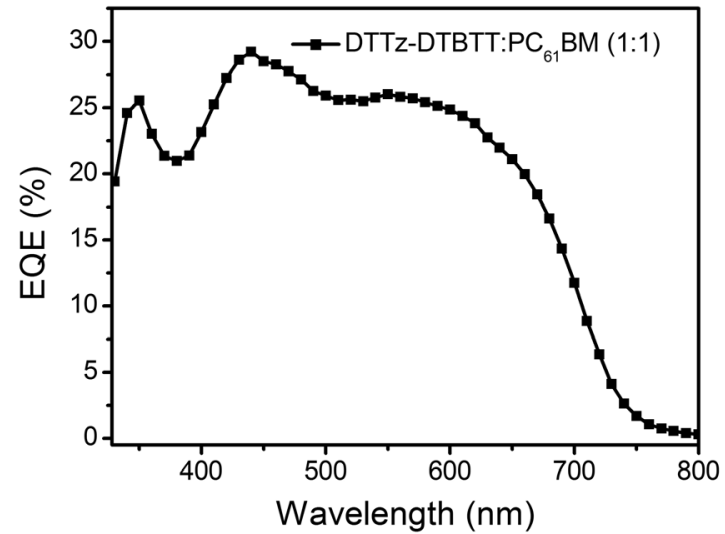

Fig. 5 EQE curve of DTTz-DTBTT and $\mathrm{PC}_{61} \mathrm{BM}(1: 1)$ based OSC devices.

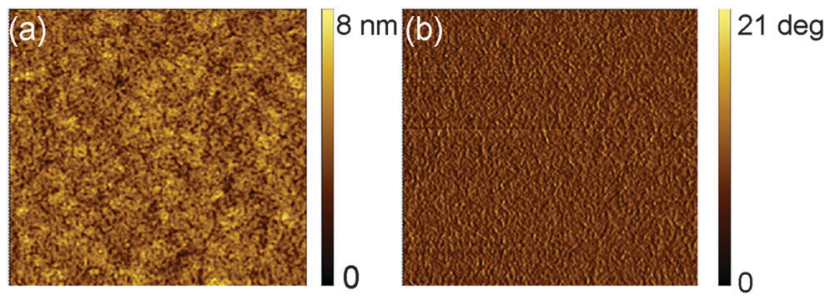

Fig. 6 AFM tapping mode height (a) and phase (b) images $(4 \mu \mathrm{m} \times 4 \mu \mathrm{m})$ of the DTTz-DTBTT: PCBM ( $w: w, 1: 1)$ film.

The morphology of the film is important for the performance of small molecule/PCBM BHJ solar cells. In order to investigate the relationship between solar cell performance and morphology, the atomic force microscopy (AFM) of the DTTz-DTBTT/PC ${ }_{61} \mathrm{BM}(\mathrm{w}: \mathrm{w}$, $1: 1)$ blend film was performed. The active layer was spin coated from $\mathrm{CHCl}_{3}$ solution onto the glass/ITO/PEDOT:PSS substrate for AFM measurements, and the topography and phase images were shown in Fig. 6. The blend film had a root mean square (rms) roughness of $0.948 \mathrm{~nm}$. The smooth surface of blend film implied good miscibility between the small molecule and $\mathrm{PC}_{61} \mathrm{BM}$, but it did not form an effective nano-scaled phase-separated interpenetrating donor-acceptor network. This may be the main reason for the low PCEs of solar cells.

\section{Conclusions}

A solution-processed small molecule DTTz-DTBTT, using a thiazolothiazole ( $\mathrm{Tz}$ ) unit as the core, has been synthesized through the Stille reaction and employed as an electron donor for small molecule organic solar cells. The small molecule exhibited good thermal stability, excellent solubility and film forming properties. The optical gap of DTTz-DTBTT was estimated to be $1.65 \mathrm{eV}$. The photovoltaic properties of DTTz-DTBTT were investigated in typical $\mathrm{BHJ}$ devices using $\mathrm{PC}_{61} \mathrm{BM}$ as an acceptor. A PCE of $1.64 \%$ was obtained with an open-circuit voltage $\left(V_{\mathrm{OC}}\right)$ of $0.66 \mathrm{~V}$, a short circuit current density $\left(J_{\mathrm{SC}}\right)$ of $5.11 \mathrm{~mA} \mathrm{~cm}^{-2}$, and a fill factor (FF) of $48 \%$. The results indicate that the molecule based on two different acceptors is an effective strategy for the design of small molecule donor materials.

\section{Acknowledgements}

The authors are deeply grateful to the National Natural Science Foundation of China (Project no. 21274134, 21202181, 21274161, 51173199), the Ministry of Science and Technology of China (2010DFA52310), New Century Excellent Talents in University (NCET-11-0473), and Qingdao Municipal Science and Technology Program (11-2-4-22-hz, 13-1-4-200-jch).

\section{References}

1 Y. Li, Acc. Chem. Res., 2012, 45, 723.

2 M. T. Dang, L. Hirsch, G. Wantz and J. D. Wuest, Chem. Rev., 2013, 113, 3734.

3 J. Roncali, Acc. Chem. Res., 2009, 42, 1719.

4 Y. Liang and L. Yu, Acc. Chem. Res., 2010, 43, 1227.

5 J. Chen and Y. Cao, Acc. Chem. Res., 2009, 42, 1709.

6 Z. He, C. Zhong, S. Su, M. Xu, H. Wu and Y. Cao, Nat. Photonics, 2012, 6, 591.

7 J. Burschka, N. Pellet, S. J. Moon, R. Humphry-Baker, P. Gao, M. K. Nazeeruddin and M. Grätzel, Nature, 2013, 499, 316.

8 L. Huo and J. Hou, Polym. Chem., 2011, 2, 2453.

9 Y. J. Cheng, S. H. Yang and C. S. Hsu, Chem. Rev., 2009, 109, 5868.

10 Y. Chen, X. Wan and G. Long, Acc. Chem. Res., 2013, 46, 2645.

11 A. K. Kyaw, D. H. Wang, V. Gupta, J. Zhang, S. Chand, G. C. Bazan and A. J. Heeger, Adv. Mater., 2013, 25, 2397.

12 (a) M. Sun, L. Wang, X. Zhu, B. Du, R. Liu, W. Yang and Y. Cao, Sol. Energy Mater. Sol. Cells, 2007, 91, 1681; (b) Y. Chen, Z. Du, W. Chen, L. Han, Q. Liu, M. Sun and R. Yang, Synth. Met., 2014, 187, 24; (c) T. Wang, Y. Chen, X. Bao, Z. Du, J. Guo, N. Wang, M. Sun and R. Yang, Dyes Pigm., 2013, 98, 11; (d) Q. Liu, Z. Du, W. Chen, L. Sun, Y. Chen, M. Sun and R. Yang, Synth. Met., 2013, 178, 38.

13 S. W. Chiu, L. Y. Lin, H. W. Lin, Y. H. Chen, Z. Y. Huang, Y. T. Lin, F. Lin, Y. H. Liu and K. T. Wong, Chem. Commun., 2012, 48, 1857.

14 W. L. Leong, G. C. Welch, L. G. Kaake, C. J. Takacs, Y. Sun, G. C. Bazan and A. J. Heeger, Chem. Sci., 2012, 3, 2103.

15 B. Walker, C. Kim and T. Q. Nguyen, Chem. Mater., 2011, 23, 470 .

16 J. Zhou, X. Wan, Y. Liu, Y. Zuo, Z. Li, G. He, G. Long, W. Ni, C. Li, X. Su and Y. Chen, J. Am. Chem. Soc., 2012, 134, 16345.

17 Y. Sun, G. C. Welch, W. L. Leong, C. J. Takacs, G. C. Bazan and A. J. Heeger, Nat. Mater., 2011, 11, 44.

18 J. Zhou, Y. Zuo, X. Wan, G. Long, Q. Zhang, W. Ni, Y. Liu, Z. Li, G. He, C. Li, B. Kan, M. Li and Y. Chen, J. Am. Chem. Soc., 2013, 135, 8484.

19 A. K. K. Kyaw, D. H. Wang, D. Wynands, J. Zhang, T. Q. Nguyen, G. C. Bazan and A. J. Heeger, Nano Lett., 2013, 13, 3796.

20 (a) Y. Chen, Z. Du, W. Chen, Q. Liu, L. Sun, M. Sun and R. Yang, Org. Electron., 2014, 15, 405; (b) X. Wan, Y. Liu, F. Wang, J. Zhou, G. Long and Y. Chen, Org. Electron., 2013, 14, 1562; (c) L. Y. Lin, C. W. Lu, W. C. Huang, Y. H. Chen, 
H. W. Lin and K. T. Wong, Org. Lett., 2011, 13, 4962; (d) J. Liu, Y. Sun, P. Moonsin, M. Kuik, C. M. Proctor, J. Lin, B. B. Hsu, V. Promarak, A. J. Heeger and T. Q. Nguyen, Adv. Mater., 2013, 25, 5898.

21 I. Osaka, M. Saito, H. Mori, T. Koganezawa and K. Takimiya, Adv. Mater., 2012, 24, 425.

22 I. Osaka, R. Zhang, G. v. Sauvé, D. M. Smilgies, T. Kowalewski and R. D. McCullough, J. Am. Chem. Soc., 2009, 131, 2521.

23 Q. Shi, P. Cheng, Y. Li and X. Zhan, Adv. Eng. Mater., 2012, $2,63$.

24 M. Sun, L. Wang, B. Du, Y. Xiong, R. Liu and Y. Cao, Synth. Met., 2008, 158, 125.

25 M. Zhang, Y. Gu, X. Guo, F. Liu, S. Zhang, L. Huo, T. P. Russell and J. Hou, Adv. Mater., 2013, 25, 4944.
26 M. Sun, L. Wang and Y. Cao, Synth. Met., 2009, 159, 556.

27 L. Huo, J. Hou, S. Zhang, H. Y. Chen and Y. Yang, Angew. Chem., Int. Ed., 2010, 49, 1500.

28 P. Sonar, S. P. Singh, Y. Li, M. S. Soh and A. Dodabalapur, Adv. Mater., 2010, 22, 5409.

29 N. Berton, C. Ottone, V. Labet, R. de Bettignies, S. Bailly, A. Grand, C. Morell, S. Sadki and F. Chandezon, Macromol. Chem. Phys., 2011, 212, 2127.

30 E. Zhou, J. Cong, S. Yamakawa, Q. Wei, M. Nakamura, K. Tajima, C. Yang and K. Hashimoto, Macromolecules, 2010, 43, 2873.

31 X. Chen, B. Liu, Y. Zou, L. Xiao, X. Guo, Y. He and Y. Li, J. Mater. Chem., 2012, 22, 17724.

32 S. Günes, H. Neugebauer and N. S. Sariciftci, Chem. Rev., 2007, 107, 1324. 